\title{
WHAT DETERMINES THE QUALITY OF MARRIAGE? EMPIRICAL VALIDATION OF THE THEORETICAL MODEL
}

\author{
UDC 159.9.072:173.1
}

\section{Milica Tošić Radev, Aleksandra Bogdanović, Vesna Anđelković}

\author{
University of Niš, Faculty of Philosophy, Department of Psychology, Niš, Serbia
}

\begin{abstract}
This study aimed to test the model set up by Obradović and ČudinaObradović, according to which marital quality is determined by certain traits of marital quality from each of these groups of factors: the personality traits of the partners, the characteristics of the marriage, the marital processes and the marital environment. We operationalized this model, by testing the effect personality traits and the tendency towards alcohol consumption of marriage partners (as a personal characteristic of the marriage partner), the duration of the marriage (as the characteristic of the marriage itself), satisfaction with the division of household responsibilities (as one of the indicators of the development of the marital processes) and doubt regarding the marriage partner's fidelity (as the feature of the wider marital environment) have on the experienced marital quality. NEO-PI-R, The Dyadic Adjustment Scale and questionnaire designed for the aims of this study were used on a sample of 199 respondents from Serbia. Our model shows an excellent fit (X2 >.05; RMSEA<.05; GFI>.90; AGFI>.90; CFI>.90; NFI>.90). It can be concluded that Neuroticism, The Duration of marriage, Doubt regarding the partner's fidelity and Dissatisfaction with the division of household responsibilities have a negative effect on marital quality.
\end{abstract}

Key words: marital quality; duration of marriage; personality, infidelity, alcohol

\section{INTRODUCTION}

There are various approaches to the definition of marital quality. Spanier (1976), for example, defines it as the mutual adjustment of the spouses, which signifies both behavioral and evaluative aspects of a marital relationship. A well-adjusted marriage is often characterized by high interaction and cohesion, low levels of disagreement, high levels of commitment to the relationship and good communication (Spanier and Lewis, 1980).

Received November 4, 2019 / Accepted January 22, 2020

Corresponding author: Vesna Anđelković

University of Niš, Faculty of Philosophy, Ćirila i Metodija 2, 18000 Niš, Serbia

E-mail: vesna.andjelkovic@filfak.ni.ac.rs 
Irrespective of how we define the quality of marital relations, many studies deal with the variables which influence marital quality. All of these determinants can be classified according to various theoretical models that emerge from them. Obradović and ČudinaObradović (1998), by integrating some of these findings, citing that in the widest, possible sense the determinants of the quality of marital relations can be divided into four broad groups of factors: 1) The personal characteristics of the marriage partners (personality traits, gender, the education of the partners, mental health, alcohol consumption), 2) The characteristics of the marriage (the duration of the marriage, the first or second marriage, etc.), 3) The interpersonal relations in the marriage or marital processes (love, communication skills, sexual relations, the division of household responsibilities), and 4) The narrow and broader marital environment (the structure of the family in childhood, children born in wedlock, the economic and political circumstances in which the family lives and various forms of stress, emotional relations outside of the marriage).

A large number of studies deal with variables that affect the marital quality and stability of couples' relationships, while personality variables are one of the most important ones. From all the theoretical backgrounds, the five-factor model of personality was used the most in studies related to marital quality, stability, and satisfaction. A great many studies indicate that there is a connection between personality traits and the quality of the marriage partner relationship. When we take neuroticism, conscientiousness, and agreeableness as predictors of marital quality into consideration, researchers mainly agree: neuroticism is negatively, and conscientiousness and agreeableness are positively linked to marital quality (Karney and Bradbury, 1997; Lavee and Ben-Ari, 2004; Shaver and Brennan, 1992). However, when it comes to the remaining two personality traits from the five-factor model, the findings are not so consistent: Extroversion and Openness are, thus, in some research a positive (Karney and Bradbury, 1995; Donnellan et al., 2004; Watson et al., 2000; Terman 1938, Obradović, 2006), and in others a negative predictors (Bentler and Newcomb, 1978; Karney and Bradbury, 1995; Shaver and Brennan, 1992).

There are a lot of personal characteristics that are related to marital quality, besides personality traits. One of them is alcohol consumption which is strongly negatively related to marital quality (Averett and Wang, 2016; Leonard and Roberts, 1996) and this relation cannot be ascribed to sociodemographic origins, personality or marital dynamics (Leonard and Roberts, 1996). Compared to women whose partners do not consume alcohol, the female partners of alcoholics evaluate their marital satisfaction as lower (Huikari et al., 2016) and more often report experiences of emotional and physical violence in the marriage (Huikari et al., 2016). The research of Leonard and Roberts (1996) indicate that "heavy" alcohol consumption (measured as the frequency of consumption and the usual amount of alcohol consumed) by either of the partners results in the decrease in marital quality.

The second group of determinants of marital quality include the characteristics of marriage. From the first studies on marital quality, the way in which the experience of marital quality changes during the course of one's life is an important point of study among researchers. One of the basic findings of these studies is that with the duration of the marriage the experience of marital quality begins to decrease very quickly following the marriage ceremony, especially following the birth of the first child (Spanier et al., 1975, Tošić Radev, 2013). Actually, the most frequent finding is the one that between the duration of the marriage and the experience of marital quality there is a U-shaped relation (Glenn, 1998; McLanahan and Adams, 1989, VanLaningham, et al., 2001). The experience of marital quality and marital satisfaction is very high in the beginning but 
then starts to decrease, then stagnates for a longer period of time at a certain level, and finally, in the post-parental period, once again rises. However, recent research (Glenn, 1998, Vaillant and Vaillant, 1993) has found that marital quality decreases continuously and that, at best, can stagnate after a long period of decline, but the experience of marital quality never improves. The decrease in the quality over time is mild but is permanent and continuous. An improvement in the experience of marital quality is connected to the departure of the children from the home and can temporarily slow down, but cannot prevent the overall decrease in happiness (VanLaningham et al., 2001).

Considering the vast increase in the participation of women in the workforce, the question of the distribution of the household responsibilities has become an important determinant of marital quality, considering that this division of household responsibilities has a tendency of being relatively traditional and unfair (Martinez et al., 2010; Mihić, Zotović and Petrović, 2006; Rogers and Amato, 2000; Tošić and Todorović, 2011). Dissatisfaction of women in terms of the division of household responsibilities has a negative effect on marital quality (Rogers and Amato, 2000), marital satisfaction (Blair, 1993; Greenstein, 1996), happiness (Suitor, 1991) and it is a significant predictor of the frequency of open marital discord (Kluwer et al., 1996) and divorce (Rogers, 1996, Blair and Johnson, 1992). On significant the other hand, the husband's involvement in household responsibilities is a predictor of positive interaction, closeness and affirmation in marital relations and can lead to an increase in marital quality and the general well-being on the part of the woman (Pina and Bengtson, 1993).

Finally, Obradović and Čudina-Obradović (1998) distinguish a lot of antecedents of marital quality from the narrow and broader marital environment: the structure of the family in childhood, various forms of stress, emotional relations outside of the marriage and so on. A not infrequent occurrence in the modern world - infidelity has certainly become an important antecedent of the quality and stability of modern marriage. Infidelity represents a partner's violation of the norms which are used to regulate the level of emotional or physical intimacy with people outside the relationship. Infidelity is one of the most detrimental factors for the love relationship and one of the most difficult problems to solve in therapy (Whisman et al., 1997). Empirical research findings also prove that any type of infidelity, ranging from virtual, online infidelity to engaging in extramarital sexual activities on the part of one of the partners, has a negative effect on the quality of partner relations and marital satisfaction (for example, Atkins et al., 2005; McDaniel et al., 2017; Treas and Giesen, 2000).

The aim of this research is to test the theoretical model by evaluating the fit of the model in which marital quality is determined by certain antecedents of marital quality from each of these groups of factors. The model assumes a large number of antecedents of marital quality and it is not possible to cover all possible predictors in one study. We opted to cover all groups of factors, choosing the following antecedents: personality traits of the individuals and the tendency of one of the spouses towards alcohol consumption (from the personal characteristics of the marriage partners group), the duration of the marriage (from the characteristics of the marriage), satisfaction with the division of household responsibilities (from marital processes group) and doubt regarding the partner's fidelity (from the marital environment). The selected antecedents are quite wellinvestigated and their importance has been proved in marriage quality studies. 


\section{Methodology}

\subsection{The sample of participants}

The sample consists of 199 married respondents (not couples) from Niš. The respondents were people from the narrow and extended social circles of the researchers who entered the sample following the snowball sampling technique. The married acquaintances entered the sample and they were asked to distribute questionnaires to their friends, colleagues and acquaintances. All of them received the printed version of tests in an envelope and the information that participation in the research is voluntary and anonymously. The sample was homogenous in terms of gender (100 men and 99 women), with an average age of 44,3 years.

\subsection{Instruments}

The respondents' personality dimensions were studied using the NEO-PI-R, a wellestablished 240-item Likert-type measure of the 5 basic personality traits: Neuroticism $(\mathrm{N})$, Extraversion (E), Openness (O), Agreeableness (A), and Conscientiousness (C). It also measures six subordinate dimensions (facets) of each of the five traits (Đurić-Jočić et al., 2004). Taken together, the five domain scales and thirty facet scales of the NEO PI-R facilitate a comprehensive and detailed assessment of normal adult personality. The psychometric characteristics of the NEO-PI-R instrument were evaluated on the Serbian population and proved to be quite good at the domain level. The scales that measure domains are marked by high reliability, with the internal consistency on the Serbian sample, the Cronbach alpha value, ranges from 0,80 to 0,90 (Knežević et al., 2004)

The Dyadic Adjustment Scale (DAS; Spanier, 1976) The DAS is the most widely used self-report measure of relationship adjustment. It is a 32-item measure developed for married couples or similar dyads and has a range of 0 to 151 for both sexes. The scale measures dyadic adjustment along the following four components: (1) Dyadic consensus is the degree of agreement that couples hold on issues of importance such as handling family finances or making major decisions. (2) Dyadic Satisfaction - the degree to which a respondent feels satisfied with their partner, the degree of happiness in the relationship, as well as the frequency of conflicts experienced in the relationship (3) Dyadic Cohesion - the degree to which the respondent and their partner participate in activities together (4) Affectional Expression - the degree to which a respondent agrees with a partner regarding emotional affection. The content, criterion-related and construct validity, as well as internal consistency reliability are adequate (Spanier, 1976). Results on the Serbian sample show that scale has high reliability (Cronbach alfa $=, 953$ ), as well as high internal consistency of subscales (DS= ,900; Dcoh= ,805; Dcon=,913; AE= ,653) (Tošić, 2011).

The questionnaire designed for the aims of this study was used to collect data on the socio-demographic variables and to study the tendencies of the partners to consume alcohol (The items included: My partner consumes alcohol and this bothers me; Alcohol is a frequent cause of discord in our marriage), satisfaction with the division of household responsibilities (I do not have sufficient support from my partner in maintaining the house; My partner does not share in the household responsibilities and other family obligations) and the existence of doubt regarding the partner's fidelity (There were situations when I suspected my partner's fidelity; My partner's infidelity would hurt me). The respondents indicated the extent of their agreement with the offered claims on a four-point scale. This 
items were developed relaying on the items in often used scales and questionnaires that examine attitudes toward alcohol, fidelity, division of household responsibilities (for example: The Prediction of Alcohol Withdrawal Severity Scale - PAWSS, Maldonado et al., 2014; A scale of attitudes towards alcohol, alcoholism and alcoholics, Vargas et al., 2008, Attitudes toward Infidelity Scale, Whatley, 2006; Susceptibility to Infidelity Instrument, Buss and Shackelford, 1997; Satisfaction with the Division of Household, Henchoz et al., 2013...). The presented study is a part of a larger research, examining a number of variables and that is the reason for using single items instead of whole scales for some variables.

\section{RESULTS}

The descriptive statistics of data used in the research are shown in the following table.

Table 1 Descriptive data

\begin{tabular}{lrrrl}
\hline & Min & Max & M & SD \\
\hline Neuroticism & 61 & 206 & 134.7 & 19.7 \\
Extraversion & 90 & 209 & 155.8 & 17.2 \\
Openness & 115 & 226 & 155.2 & 16.3 \\
Agreeableness & 98 & 205 & 161.5 & 17.6 \\
Conscientiousness & 132 & 238 & 179.2 & 18.4 \\
Marital quality & 12 & 148 & 111.7 & 24.9 \\
Duration of the marriage & 1 & 55 & 17.1 & 12.3 \\
Alcohol consumption & 2 & 8 & 1.47 & .92 \\
Satisfaction with the division of household responsibilities & 2 & 7 & 1.94 & 1.06 \\
Doubt regarding the partner's fidelity & 1 & 8 & 1.72 & .99 \\
\hline
\end{tabular}

By comparing the average scores of the personality traits in our sample with the norms obtained by the standardization of the NEO PI-R questionnaire (Knežević et al., 2004) we can register an increase in all the dimensions, (Norms: $\mathrm{N}=88.14 ; \mathrm{E}=102.96$; $\mathrm{O}=109.09 ; \mathrm{A}=119.79 ; \mathrm{C}=125.41)$. Such results are justified by the fact that the results, on our population in recent years, regularly receive similar increases compared to the norms (e.g. Šundrić and Stojiljković, 2006, Stanković and Stojiljković, 2006).

The average value (Mean $=111.7$ ) on DAS scale in our sample is high and indicates the experience of the high quality of the marriage of our respondents. The average duration of the marriage is 17 years, in the range of 1 to 55 years. The tendency for alcohol consumption, as well as doubt of the partner's fidelity on average were rated lower than the theoretical mean values. Satisfaction with the division of household responsibilities also does not exceed the theoretical mean value, which is in accordance with the expectations based on the research results obtained previously in our environment (e.g. Mihić, Zotović and Petrović, 2006). Gender differences (independent samples t-tests) were found for Openness $(\mathrm{p}=.008)$, Satisfaction with the division of household responsibilities $(\mathrm{p}=.000)$ and the Alcohol consumption by the spouse $(\mathrm{p}=.000)$. Namely, women had statistically significantly higher scores on all the mentioned variables.

In order to evaluate the specified relations between the dimensions of personality traits of individuals, the tendency for alcohol consumption on part of one of the partners, the 
duration of the marriage, satisfaction with the distribution of household responsibilities, alcohol consumption on the part of the spouse and the existence of doubt regarding the fidelity of the partner and their effects on marital quality, we used the method of path analysis, that is, structural equation modeling. All of the variables in the model were manifest. The results of the tested model are shown in table 2. At the same time, the theoretical model created by Obradović and Čudina-Obradović was expanded by the assumed relations existing between the predictor variables themselves. It was namely assumed that there was a mutual connection between the duration of marriage and the personality traits, the tendency towards alcohol consumption on the part of one of the spouses, dissatisfaction with the division of household responsibilities and doubt regarding the partner's fidelity, as show in graph 1.

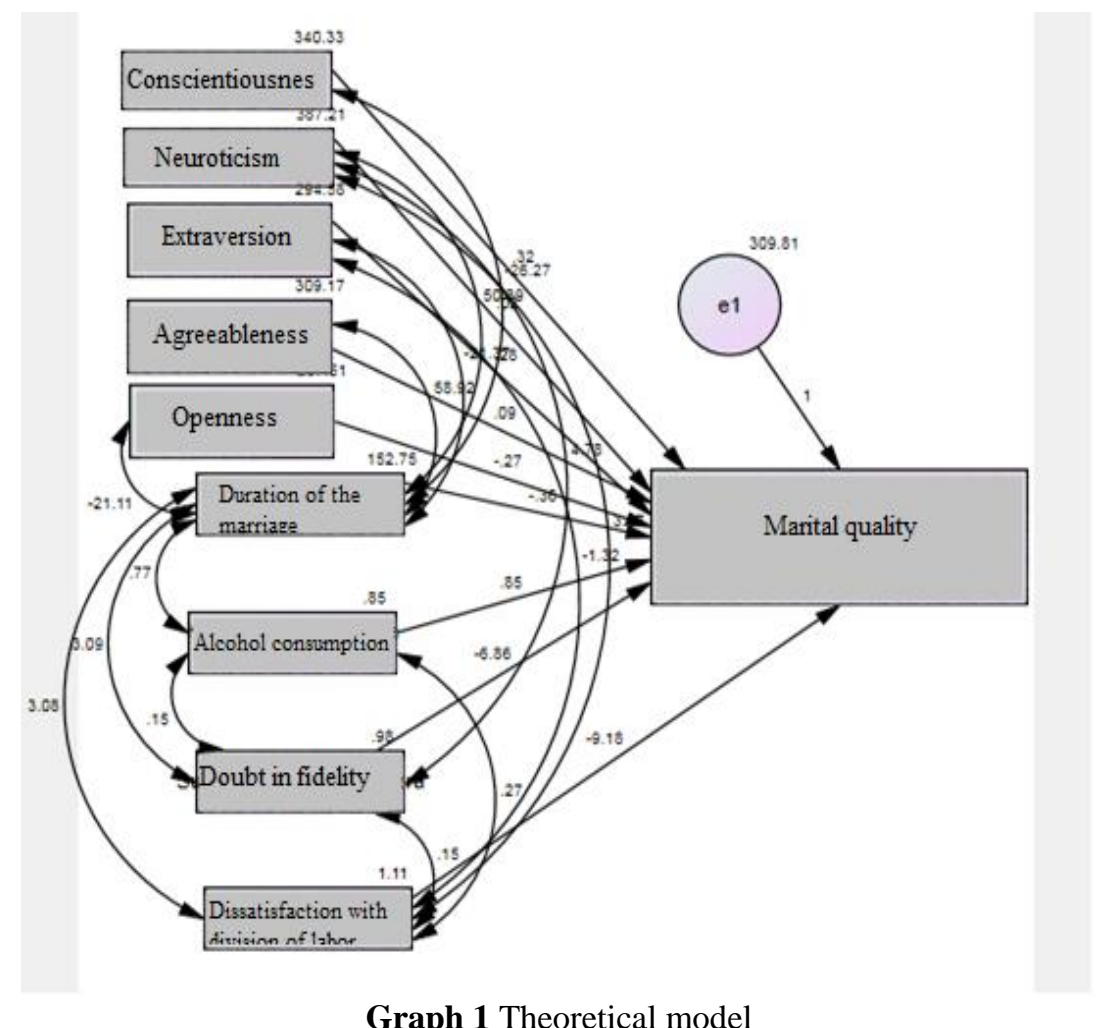

Graph 1 Theoretical model

Table 2 Parameter coefficient estimates and measures of model fit for theoretical model of the determinants of marital quality

\begin{tabular}{cccccccc}
\hline $\mathrm{X}^{2}$ & Df & P & RMSEA & GFI & AGFI & CFI & NFI \\
\hline 229.47 & 22 & .000 & .218 & .828 & .569 & .501 & .502 \\
\hline
\end{tabular}

The results shown in table 2 point out that the initial model did not indicate an adequate fit with the empirical data. A more detailed analysis indicated the possibility of 
model modification, by removing the variables which did not have significant effects on marital quality. Those are the following personality traits: agreeableness, openness, and conscientiousness.

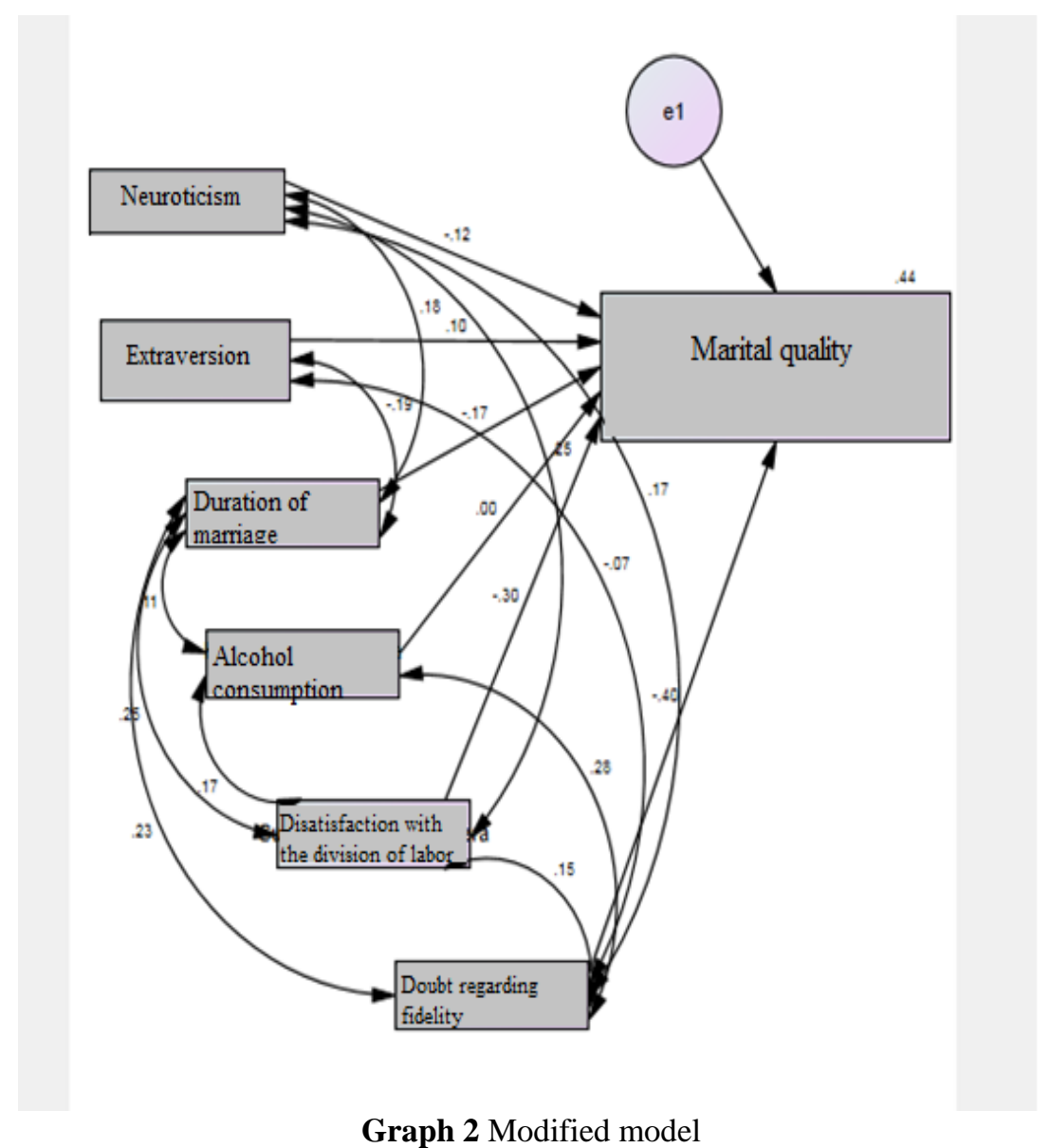

Table 3 Parameter coefficient estimates and measures of model fit for modified model of the determinants of marital quality

\begin{tabular}{cccccccc}
\hline $\mathrm{X}^{2}$ & Df & $\mathrm{P}$ & RMSEA & GFI & AGFI & CFI & NFI \\
\hline 3.148 & 4 & .533 & .000 & .996 & .969 & 1.000 & .984 \\
\hline
\end{tabular}

The results shown in table 3 indicate that the modified model suits the data more appropriately. All of the parameters indicate an excellent fit $\left(\mathrm{X}^{2}>.05\right.$; RMSEA<.05; GFI>.90; AGFI>.90; CFI>.90; NFI>.90). More specifically, even the absolute indicators of the fit (the chi-square value, as well as the relation between the chi-square and the number of degrees of freedom) and the relative indicators of the fit (CFI, GFI) indicate that the data fit well into the assumed model. In addition, the RMSEA value of .000 indicates the perfect fit of the testing model. In other words, among the referent 
measures, all of the indicators point to an especially well fit of the data into the theoretical model, according to the criteria of a good and appropriate fit which is recommended by Schermelleh-Engel et al. (2003).

Table 4 Standardized regression coefficients - a modified model

\begin{tabular}{lrc}
\hline & $\begin{array}{c}\text { Regression } \\
\text { coefficient }\end{array}$ & $\mathrm{p}$ \\
\hline Neuroticism & -.119 & .033 \\
Extraversion & .100 & .066 \\
Duration of the marriage & -.173 & .003 \\
Alcohol consumption & .005 & .934 \\
Satisfaction with the division of household responsibilities & -.397 & .000 \\
Doubt regarding the partner's fidelity & -.298 & .000 \\
\hline
\end{tabular}

By analyzing the direction of the regression coefficients, it can be concluded that Neuroticism, Duration of marriage, Doubt regarding the partner's fidelity and Dissatisfaction with the division of household responsibilities have a statistically significant and negative effect on quality of marriage, while Extroversion and Tendency toward alcohol consumption do not predict marital quality.

\section{DISCUSION AND CONCLUSIONS}

In this study, we tested the theoretical model which attempts to integrate the findings of numerous studies regarding the determinants of marital quality. From a large number of antecedents of marital quality that this theoretical model assumes, we chose the ones that are most commonly investigated in marriage quality studies, based on the author's literature search, respecting the rule that each group of determinants should be represented.

Personality traits of the individuals and the tendency of one of the spouses towards alcohol consumption are antecedents from the first group of determinants, the personal characteristics of the marriage partners, in the theoretical model by Obradović and Čudina-Obradović (1998). The spouse's personality is the indispensable determinant of marital quality whose relevance for marital satisfaction has been supported by numerous studies. Another important personal characteristic, with documented effects on marital quality, is a tendency towards alcohol consumption. We selected to include this variable in the model as a representation of our partner's (not our own) personal characteristic that may influence our perception of quality of life in marriage and also, this personal characteristic is not a permanent personality trait like the NEO PI R dimensions. The duration of the marriage was selected to represent the group of the characteristics of the marriage. Finally, satisfaction with the division of household responsibilities and doubt regarding the partner's fidelity, as the most common and pervasive problems in modern marriages, are selected to represent antecedents of marital quality from the following groups of factors: marital processes and the marital environment.

Our findings suggest the accuracy of this integrative model of marital quality, considering the exceptionally fine fit of the empirical data into the theoretical model. In other words, the structural modeling confirmed that four broad groups of factors, that is, the personal traits of the partners, the characteristics of the marriage, interpersonal 
relations in the marriage or marital processes, as well as the broader or narrower marital environment are very good predictors of marital quality. Namely, it has been proven that neuroticism, the length of the duration of the marriage, doubt regarding the partner's fidelity and lack of satisfaction with the division of household responsibilities create a negative effect on marital quality. The parameters of fitting for this model were excellent.

Neuroticism is a personality dimension that is characterized by a negative emotional state and instability (Bouchard et al., 1999), while its more essential aspects are anxiety, hostility, depression, social anxiety, impulsivity, and vulnerability. There is clear evidence of the existence of a negative effect of neuroticism for both spouses on the various aspects of marital adjustment and marital quality (Bouchard et al., 1999). Previous studies offer potential explanations for those findings, suggesting that emotionally unstable people can be often unsatisfied or pessimistic (Cote' and Moskowitz, 1998) and, by doing so, elicit negative life events (Caughlin, Huston, and Houts, 2000), they can have negative interaction behaviors (Caughlin et al., 2000), inadequate coping strategies used during conflict (Bouchard, 2003) or insecure attachment styles (Hazan and Shaver, 1987).

The quality of the marriage decreases with its duration. This finding is in accordance with the abundance of existing findings on this topic. It can be concluded, summarizing the results of numerous studies that the perceived quality of marriage is highest at the beginning of the marriage and then decreases continuously or stagnates at a low level. This is a characteristic of most marriages as a consequence of inevitable developmental changes (Tošić Radev, 2013). VanLaningham et al. (2001) consider that numerous means can be used to explain any changes in the experience of the quality of marriage and its duration, starting from the adjustment of the individual to more realistic expectations of marriage, changes in the family structure and roles, getting used to the responsibilities of married life and facing numerous challenges, such as a fair division of household responsibilities, the redefinition of the relations with relatives or solving conflicts, etc.

Besides, the results show that the dissatisfaction of the division of household responsibilities and doubt regarding the fidelity of the partner are significant predictors with the biggest regression coefficients on the marital quality, which is in accordance with results registered in previous studies (Rogers and Amato, 2000; Ogolsky et al., 2014). The research of Ogolsky et al. (2014) indicates that marital quality is best in the situations when partners have similar attitudes on the division of responsibilities, whether it is traditional or not. Similarly, by reviewing numerous findings, Tošić and Todorović (2011) cite that the distribution of responsibilities is not the most important feature of marital quality. It is the perception of the just or unjust nature of that division, which primarily depends on the adopted gender ideology and attitudes toward gender roles of both spouses.

Previous findings also suggest that doubt regarding the fidelity or the discovered infidelity of the partner diminish a quality of marriage (Previti and Amato, 2004). However, they found that infidelity was both a cause and a consequence of marital discord. Recent work (Tafoya and Spitzberg, 2007) emphasizes the communicative functions of infidelity, i.e. the intentions to maintain, repair, or terminate the primary relationship.

Regarding the other antecedents from the model, marital quality was not significantly predicted by the extraversion of the individual and with the partner's tendency towards alcohol consumption.

Previous findings that studied the relations between extraversion and marital quality were inconsistent (for example, Donnellan et al., 2004; Watson et al., 2000). The authors of the studies which determined a positive connection between extraversion and the different dimensions of the quality of marriage indicate that the tendency towards a 
positive emotional state (Ahmetoglu et al., 2010), open displays of love (Taraban et al., 1998) and skillful handling of oneself in social interaction (Funder et al., 2000) are some of the characteristics which contribute to the quality of their marital relations.

In the case of the partner's tendency towards alcohol consumption, whose effect was not significant, we should bear in mind that the descriptive data show that the extent of the tendency towards alcohol consumption in our sample was not evaluated as high by the partners. This means that we did not have participants who frequently and intensely consume alcohol, which might lead this factor to have significant effect. Recent research (Levitt and Cooper, 2010; Levitt and Leonard, 2012; Livingston, 2009) showed that moderate alcohol consumption can have a positive effect on marital adjustment and functionality because it can be tied to a more active social life on the part of both partners and their greater participation in various activities in the community. Certainly, there is a need for further studies aiming to explore this statement and the general effect of alcohol consumption. Another problem is that we did not use standard instrument to assess the tendency toward alcohol consumption, thus variability in the intensity of alcohol consumption is reduced (cases of "severe" alcohol consumptions are excluded).

Bearing in mind that the determinants of the quality of marriage with the highest predictive power in the model are different for men and women, one shortcoming of the study is that the analysis was not done separately for men and women. Because a small size of subsamples based on gender, on which it is not recommended to use structural equation modeling, we decide not to test the model on subsamples. In addition to not being one of the research questions of the study, the main reason for a such decision is the fact that the results obtained on a small sample as well as the discussion and conclusions would not be accurate and reliable. Anyway, it remains doubtful whether this model of marriage quality is applicable for men, given the large gender differences in the variable that is the most significant predictor in the model: Satisfaction with the division of household responsibilities.

Finally, only some of the antecedents were tested in the model, so the effects of other determinants should be checked in future research. Also, it can be assumed that some of the antecedents are mediators in the relationship between personality traits and marital quality, which also may be the subject of subsequent studies.

However, implications of this research are valuable because it provides empirical verification for integrative model of marital quality, considering the exceptionally fine fit of the empirical data into the theoretical model, and illuminates the importance of antecedents on marital quality. Finally, some of these antecedents, those representing marital processes and the marital environment, can be controlled by an individual, so they might be used for strengthening the satisfaction of the spouses and improving the wellbeing of the families. Namely, the quality of marriage will be worse if spouses allow one partner have a reason to feel that he or she has been forced into an unfair division of labor or his or her trust in the partner's fidelity is broken. Investing effort into building a relationship of mutual respect and trust and good, effective communication between the partners could be beneficial for improving the quality of a marriage.

Acknowledgement: This research was supported by a research grant of the Faculty of Philosophy in Niš within the framework of the "Applied psychology in a function of the quality of life of an individual in the community" project. 


\section{REFERENCES}

Ahmetoglu, Gorkan, Viren Swami, and Tomas Chamorro-Premuzic. "The relationship between dimensions of love, personality, and relationship length". Archives of Sexual Behavior 39, 5 (2010): 1181-1190.

Atkins, David C., et al. "Infidelity in couples seeking marital therapy". Journal of Family Psychology 19, 3 (2005): 470 .

Averett, Susan L., and Yang Wang. "Identifying the causal effect of alcohol abuse on the perpetration of intimate partner violence by men using a natural experiment". Southern Economic Journal 82, 3 (2016): 697-724. doi:10.1002/soej.12104

Ben-Ari, Adital, and Yoav Lavee. "Dyadic characteristics of individual attributes: Attachment, neuroticism, and their relation to marital quality and closeness." American Journal of Orthopsychiatry 75.4 (2005): 621-631.

Bentler, Peter M., and Michael D. Newcomb. "Longitudinal study of marital success and failure". Journal of Consulting and Clinical Psychology 46, 5 (1978): 1053-1070.

Blair, Sampson Lee, and Michael P. Johnson. "Wives' perceptions of the fairness of the division of household labor: The intersection of housework and ideology". Journal of Marriage and the Family 54, 3 (1992): $570-581$.

Blair, Sampson Lee. "Employment, family, and perceptions of marital quality among husbands and wives." Journal of Family Issues 14, 2 (1993): 189-212.

Bouchard, Geneviève, Yvan Lussier, and Stéphane Sabourin. "Personality and marital adjustment: Utility of the five-factor model of personality." Journal of Marriage and the Family (1999): 651-660.

Bouchard, Geneviève. "Cognitive appraisals, neuroticism, and openness as correlates of coping strategies: An integrative model of adaptation to marital difficulties". Canadian Journal of Behavioural Science/Revue canadienne des sciences du comportement 35, 1 (2003): 1-12.

Buss, D. M. and T. K. Shackelford. "Susceptibility to infidelity in the first year of marriage". Journal of Research in Personality 31 (1997): 193-221.

Caughlin, John P., Ted L. Huston, and Renate M. Houts. "How does personality matter in marriage? An examination of trait anxiety, interpersonal negativity, and marital satisfaction". Journal of Personality and Social Psychology 78, 2 (2000): 326.

Côté, Stéphane, and Debbie S. Moskowitz. "On the dynamic covariation between interpersonal behavior and affect: prediction from neuroticism, extraversion, and agreeableness". Journal of Personality and Social Psychology 75, 4 (1998): 1032-1046.

Čudina-Obradović, Mira, and Josip Obradović. Psihologija braka i obitelji. Zagreb: Golden marketing-tehnička knjiga, 2006.

Donnellan, M. Brent, Rand D. Conger, and Chalandra M. Bryant. "The Big Five and enduring marriages". Journal of Research in Personality 38, 5 (2004): 481-504.

Đurić-Jočić, Dragana, Tamara Džamonja-Ignjatović, and Goran Knežević. Neo Pi-R: primena i interpretacija. Beograd: Centar za primenjenu psihologiju, 2004.

Funder, David C., R. Michael Furr, and C. Randall Colvin. "The Riverside Behavioral Q-sort: A tool for the description of social behavior". Journal of Personality 68, 3 (2000): 451-489.

Glenn, Norval D. "The course of marital success and failure in five American 10-year marriage cohorts." Journal of Marriage and the Family (1998): 569-576. doi:10.2307/353529

Greenstein, Theodore N. "Husbands' participation in domestic labor: Interactive effects of wives' and husbands' gender ideologies". Journal of Marriage and the Family (1996): 585-595.

Hazan, Cindy, and Phillip Shaver. "Romantic love conceptualized as an attachment process". Journal of Personality and Social Psychology 52, 3 (1987): 511-524.

Henchoz, Caroline, et Boris Wernli. "La satisfaction des couples en Suisse face à la répartition des tâches ménagères: une approche longitudinale“. Population 68, 4 (2013): 533-556.

Huikari, Sanna, Marko Korhonen, and Mikko Puhakka. "'Til booze do us part: Alcohol consumption and marital dissolution." Empirical Economics 51, 2 (2016): 831-852. doi:10.1007/s00181-015-1017-9

Karney, Benjamin R., and Thomas N. Bradbury. "Neuroticism, marital interaction, and the trajectory of marital satisfaction." Journal of Personality and Social Psychology 72, 5 (1997): 1075.

Kluwer, Esther S., Jose AM Heesink, and Evert Van de Vliert. "Marital conflict about the division of household labor and paid work." Journal of Marriage and the Family (1996): 958-969.

Knežević, Goran, Tamara Džamonja-Ignjatović, and Dragana Đurić-Jočić. Petofaktorski model ličnosti. Beograd: Centar za primenjenu psihologiju, 2004.

Leonard, Kenneth E., and Linda J. Roberts. "Marital aggression, quality, and stability in the first year of marriage: Findings from the Buffalo Newlywed Study." The Developmental Course of Marital Dysfunction (1998): 44-73. 
Levitt, Ash, and M. Lynne Cooper. "Daily alcohol use and romantic relationship functioning: Evidence of bidirectional, gender-, and context-specific effects." Personality and Social Psychology Bulletin 36, 12 (2010): 1706-1722.

Levitt, Ash, and Kenneth E. Leonard. "Relationship-specific alcohol expectancies and relationship-drinking contexts: Reciprocal influence and gender-specific effects over the first 9 years of marriage." Psychology of Addictive Behaviors 27, 4 (2013): 986

Livingston, Michael. "Effects of alcohol consumption in spousal relationships on health-related quality of life and life satisfaction." Journal of Studies on Alcohol and Drugs 70, 3 (2009): 383-390.

Maldonado, José R., et al. "The "Prediction of Alcohol Withdrawal Severity Scale"(PAWSS): Systematic literature review and pilot study of a new scale for the prediction of complicated alcohol withdrawal syndrome." Alcohol 48, 4 (2014): 375-390.

McDaniel, Brandon T., Michelle Drouin, and Jaclyn D. Cravens. "Do you have anything to hide? Infidelityrelated behaviors on social media sites and marital satisfaction." Computers in Human Behavior 66 (2017): $88-95$

McLanahan, Sara, and Julia Adams. "The effects of children on adults' psychological well-being: 19571976." Social Forces 68, 1 (1989): 124-146.

Mihić, Ivana, Zotović Marija, Petrović Jelica. "Sociodemografske karakteristike porodice, podela posla u kući I vaspitni stilovi roditelja u porodicama na teoritoriji Vojvodine.” Pedagoška stvarnost 1-2 (2006): 118-134.

Obradovic, Josip and Cudina-Obradovic, Mira "Correlates of subjective global marital satisfaction in women." Drustvena istrazivanja 9, 1; ISSU 45 (2000): 41-66.

Obradović, Josip i Mira Čudina Obradović. "Bračna kvaliteta: poimanje, uzroci i posledice". Društvena istraživanja 7 (1998): 659-682.

Ogolsky, Brian G., Renée Peltz Dennison, and James Kale Monk. "The role of couple discrepancies in cognitive and behavioral egalitarianism in marital quality." Sex Roles 70, 7-8 (2014): 329-342. doi:10.1007/s11199014-0365-9

Pina, Darlene L., and Vern L. Bengtson. "The division of household labor and wives' happiness: Ideology, employment, and perceptions of support." Journal of Marriage and the Family (1993): 901-912.

Previti, Denise, and Paul R. Amato. "Is infidelity a cause or a consequence of poor marital quality?" Journal of Social and Personal Relationships 21, 2 (2004): 217-230.

Radev, Milica Tošić. "Kvalitet braka i determinante porodičnog okruženja". Godisnjak za psihologiju 10, 12 (2013): 2-2

Rodriguez, Lindsey M., Clayton Neighbors, and C. Raymond Knee. "Problematic alcohol use and marital distress: An interdependence theory perspective." Addiction Research and Theory 22, 4 (2014): 294-312.

Rogers, Stacy J., and Paul R. Amato. "Have changes in gender relations affected marital quality?" Social Forces 79, 2 (2000): 731-753.

Rogers, Stacy J. "Mothers' work hours and marital quality: Variations by family structure and family size." Journal of Marriage and the Family (1996): 606-617.

Schermelleh-Engel, Karin, Helfried Moosbrugger, and Hans Müller. "Evaluating the fit of structural equation models: Tests of significance and descriptive goodness-of-fit measures." Methods of Psychological Research Online 8, 2 (2003): 23-74.

Shaver, Phillip R., and Kelly A. Brennan. "Attachment styles and the 'Big Five' personality traits: Their connections with each other and with romantic relationship outcomes." Personality and Social Psychology Bulletin 18, 5 (1992): 536-545.

Spanier, Graham B., and Robert A. Lewis. "Marital quality: A review of the seventies." Journal of Marriage and the Family 42, 4 (1980): 825-839.

Spanier, Graham B., Robert A. Lewis, and Charles L. Cole. "Marital adjustment over the family life cycle: The issue of curvilinearity." Journal of Marriage and the Family (1975): 263-275.

Spanier, Graham B. "Measuring dyadic adjustment: New scales for assessing the quality of marriage and similar dyads." Journal of Marriage and the Family (1976): 15-28. doi:10.2307/350547

Stanković, Jovana i Snežana Stojiljković. "Dimenzije ličnosti, inteligencija i moralno rasuđivanje adolescenata”. U Primenjena psihologija (Zbornik radova), 391-407. Niš: Filozofski fakultet, 2006.

Suitor, J. Jill. "Marital quality and satisfaction with the division of household labor across the family life cycle." Journal of Marriage and the Family (1991): 221-230.

Šundrić, J. i Snežana Stojiljković. Perfekcionizam i bazične dimenzije ličnosti muzički nadarenih osoba (diplomski rad). Niš: Filozofski fakultet, 2006

Tafoya, M. A., and B. H. Spitzberg. "Communicative infidelity." The Dark Side of Interpersonal Communication (2007): 199-242.

Treas, Judith, and Deirdre Giesen. "Sexual infidelity among married and cohabiting Americans." Journal of Marriage and Family 62, 1 (2000): 48-60. 
Taraban, Carolyn B., Susan S. Hendrick, and Clyde Hendrick. "Loving and liking." Handbook of Communication and Emotion, 331-351. Academic Press, 1996.

Tošić, Milica i Dušan Todorović. "Podela rada, kvalitet braka i rodna ideologija". Sociološki pregled 44, 3 (2011): 393-419.

Vargas, Divane de, and Margarita Antonia Villar Luis. "Development and validation of a scale of attitudes towards alcohol, alcoholism and alcoholics." Revista Latino-americana de Enfermagem 16, 5 (2008): 895-902.

VanLaningham, Jody, David R. Johnson, and Paul Amato. "Marital happiness, marital duration, and the Ushaped curve: Evidence from a five-wave panel study." Social Forces 79, 4 (2001): 1313-1341.

Watson, David, Brock Hubbard, and David Wiese. "General traits of personality and affectivity as predictors of satisfaction in intimate relationships: Evidence from self-and partner-ratings." Journal of Personality 68, 3 (2000): 413-449. doi:10.1111/1467-6494.00102

Whisman, Mark A., Amy E. Dixon, and Benjamin Johnson. "Therapists' perspectives of couple problems and treatment issues in couple therapy." Journal of Family Psychology 11, 3 (1997): 361.

\section{ODREDNICE KVALITETA BRAKA: EMPIRIJSKA VALIDACIJA TEORIJSKOG MODELA}

Cilj ovog istraživanja je da proveri model, pretpostavljen od strane Obradovića i ČudineObradović, po kome se odrednice kvaliteta braka grupišu oko ličnih karakteristika bračnih partnera, karakterisika samog braka, interpersonalnih odnosa u braku i bračnog okruženja, koristeći odabrane indikatore iz svakog od ovih domena. Testiran je efekat dimenzija ličnosti $i$ sklonost ka uzimanju alkohola partnera (lične karakteristike bračnih partnera), dužina braka (karakteristike braka), zadovoljstvo podelom kućnih poslova (bračni procesi) i sumnja u partnerovu vernost (bračno okruženje) na doživljeni kvalitet braka. Inventar ličnosti NEO PI-R (Đurić-Jočić i sar., 2004), Skala uzajamne prilagodjenosti partnera - DAS (Spanier, 1976) i upitnik sačinjen za potrebe ovog istraživanja korišćeni su na uzorku ispitanika sa teritorije južne Srbije $(N=199)$ koji su u trenutku ispitivanja bili u braku. Dobijeni rezultati pokazuju da su parametri fitovanja za postavljeni model odlični (X2 >.05; RMSEA<.05; GFI>.90; AGFI>.90; CFI>.90; NFI>.90). Zaključujemo da Neuroticizam, Dužina trajanja braka, Sumnja u partnerovu vernost $i$ Nezadovoljstvo podelom kućnih poslova ostvaruju negativan efekat na kvalitet braka.

Ključne reči: kvalitet braka, dužina braka, dimenzije ličnosti, neverstvo, podela kućnih poslova. 